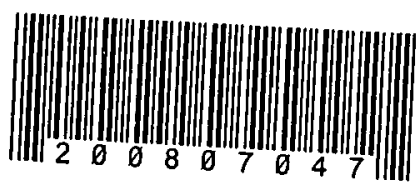

\title{
APPLICATION OF THE CONVENTION ON THE PREVENTION AND PUNISHMENT OF THE CRIME OF GENOCIDE (BOSNIA AND HERZEGOVINA V SERBIA AND MONTENEGRO)
}

\author{
STATHIS PALASSIS*
}

\section{INTRODUCTION}

On 26 February 2007 the International Court of Justice ('ICJ') handed down its long-awaited judgment in the case concerning application of the Convention on the Prevention and Punishment of the Crime of Genocide (Bosnia and Herzegovina $v$ Serbia and Montenegro). ${ }^{\prime}$ The Court adjudicated alleged violations by Serbia and Montenegro ('Serbia') of the Convention on the Prevention and Punishment of the Crime of Genocide, ${ }^{2}$ examining whether genocide occurred during the secession of Bosnia and Herzegovina ('Bosnia') and, if it did, whether those actions could be attributed to Serbia. The Court found that Serbia had not committed genocide, but had violated obligations to prevent genocide and to cooperate fully with the International Criminal Tribunal for the former Yugoslavia ('ICTY'). ${ }^{3}$ The Court also found that the award of compensatory damages was not appropriate in this case. The case has generated public division over the Court's reasoning on difficult jurisdictional questions, as well as the characterisation of, and responsibility for, atrocities committed. The fact alone that the case concerns alleged breaches of the jus cogens prohibition on genocide makes the case significant.

- BJuris, LLB (University of Western Australia); SJD (University of Sydney); Senior Lecturer in International Law, Faculty of Law, University of Technology, Sydney; Solicitor of the Supreme Court of New South Wales. The author thanks Stefanie Duncan and Danka Suvajlo for their research.

1 (Judgment), International Court of Justice, 26 February $2007<$ http://www.icj-

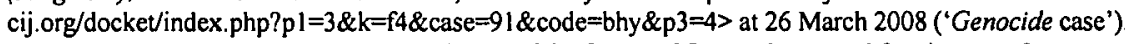

2 Convention on the Prevention and Punishment of the Crime of Genocide, opened for signature 9 December 1948, 78 UNTS 277 (entered into force 12 January 1951) ('Genocide Convention')

3 The International Criminal Tribunal for the former Yugoslavia ('ICTY') was established on 8 May 1993 pursuant to Security Council Resolution 808: SC Res 808, UN SCOR, $48^{\text {th }}$ sess, $3175^{\text {th }} \mathrm{mtg}$, UN Doc S/Res/808 (1993) ('Resolution 808'). The Tribunal's establishment is provided for by Security Council resolution 827: Establishment of the International Criminal Tribunal for the former Yugoslavia SC Res 827, UN SCOR, 48 ${ }^{\text {th }}$ sess, 321 $7^{\text {th }} \mathrm{mtg}$, UN Doc S/Res/827 (1993) ('Resolution 827'). The Tribunal's Statute ('ICTY Statute') was originally published as Annex to the Report of the Secretary-General pursuant to [2] of Resolution 808 


\section{THE FACTS}

Until its dissolution in the early 1990s the Socialist Federal Republic of Yugoslavia ('SFRY') occupied a large part of the Balkan Peninsula. ${ }^{4}$ During its dissolution regional ethnic, religious and territorial tensions flared up, resulting in frequent and serious breaches of norms of international criminal law, particularly in Bosnia. On 20 March 1993 Bosnia initiated proceedings against the Federal Republic of Yugoslavia ('FRY') seeking recognition of Serbia's responsibility for ethnic cleansing and other atrocities committed in Bosnia. The claim was based on apprehended violations by Serbia of international obligations owed to Bosnia under the Genocide Convention.

As the conflict was still continuing when proceedings were commenced, Bosnia also filed a request for the indication of provisional measures and then further requests for the indication of provisional measures. In the order of 8 April 1993, the Court unanimously ordered that the FRY take all measures within its power to prevent commission of genocide. ${ }^{5}$ Further, the Court indicated by thirteen to one that the FRY should

ensure that any military, paramilitary or irregular armed units which may be directed or supported by it, as well as any organisations and persons which may be subject to its control, direction or influence, do not commit any acts of genocide, of conspiracy to commit genocide, of direct and public incitement to commit genocide, or of complicity in genocide. ${ }^{6}$

In the order of 13 September 1993 the Court by thirteen to two reaffirmed the provisional measures indicated in paragraphs $52 \mathrm{~A}(1)$ and $(2)$ of the order of 8 April 1993. In a separate opinion, Judge ad hoc Lauterpacht indicated that the prohibitions should have contained further details. In particular, the prohibition should have extended to the provision of weapons, ammunition, military supplies and financial, commercial or any other aid, except of a strictly humanitarian character, to any forces, authorities or individuals involved in the hostilities, and to 'ethnic cleansing' ${ }^{8}$ His Excellency then added that both sides must, inter alia, comply with the ceasefire, release all detainees, allow free movement within

4 The Democratic Federal Yugoslavia was created in 1943, renamed the Federal People's Republic of Yugoslavia in 1946, and then the Socialist Federal Republic of Yugoslavia ('SFRY') in 1963. Its territory covered the present states of: Bosnia and Herzegovina ('Bosnia'), Croatia, the Former Yugoslav Republic of Macedonia, Kosovo, Montenegro, Serbia, and Slovenia. The SFRY was disintegrated between 1991 and 1992, and replaced by successor states. The Federal Republic of Yugoslavia ('FRY'), comprising the republics of Serbia and Montenegro, existed between 1992 and 2003. In 2003 it was reconstituted as confederated Serbia and Montenegro, and in June 2006 Montenegro declared its independence. Kosovo was an international protectorate and part of Serbia until its declaration of independence on 17 February 2008.

5 Application of the Convention on the Prevention and Punishment of the Crime of Genocide (Bosnia and Herzegovina v Yugoslavia (Serbia and Montenegro)) (Request for the Indication of Provisional Measures) [1993] ICJ Rep 3, [52A(1)].

6 Ibid $[52 \mathrm{~A}(2)]$

7 Application of the Convention on the Prevention and Punishment of the Crime of Genocide (Bosnia and Herzegovina v Yugoslavia (Serbia and Montenegro)) (Further Requests for the Indication of Provisional Measures) [1993] ICJ Rep 325, [61]. 
Bosnia, refrain from further destruction of ethnical and cultural institutions, and to immediately end all discriminatory acts. ${ }^{9}$

There were also two previous judgments in the case, those of 11 July 1996 and 3 February 2003. The judgment of 11 July 1996 concerns preliminary objections between 29 April and 3 May 1996. ${ }^{10}$ The objections primarily concern jurisdiction and the FRY's status vis-à-vis the SFRY and the extent of the FRY's international obligations. The Court dismissed FRY's objections and found that at the time of application there was jurisdiction conferred by Article IX of the Genocide Convention. ${ }^{11}$ The Court pointed to a diplomatic note dated 27 April 1992 from Yugoslavia's Permanent Mission to the United Nations ('UN') Secretary-General where it was stated, inter alia, that:

The assembly of the Socialist Federal Republic of Yugoslavia, at its session held on 27 April 1992, promulgated the Constitution of the Federal Republic of Yugoslavia. Under the Constitution, on the basis of the continuing personality of Yugoslavia and the legitimate decisions by Serbia and Montenegro to continue to live together in Yugoslavia, the Socialist Federal Republic of Yugoslavia is transformed into the Federal Republic of Yugoslavia, consisting of the Republic of Serbia and the Republic of Montenegro.

Strictly respecting the continuity of the international personality of Yugoslavia, the Federal Republic of Yugoslavia shall continue to fulfil all the rights conferred to, and obligations assumed by the Socialist Federal Republic of Yugoslavia in international relations, including its membership in all international organizations and participation in international treaties ratified or acceded to by Yugoslavia. ${ }^{12}$

The judgment of 3 February 2003 concerns an application for revision of the 1996 judgment. ${ }^{13}$ Based on certain new information: that the FRY was not a UN member until 1 November 2000; that it did not continue the personality of the SFRY; and was at material times not a UN member, not party to the Statute of the International Court of Justice, ${ }^{14}$ and not party to the Genocide Convention, Yugoslavia applied for revision of the 1996 judgment. $^{15}$ The Court found

$9 \quad$ Ibid [124]

10 Application of the Convention on the Prevention and Punishment of the Crime of Genocide (Bosnia and Herzegovina v Yugoslavia) (Preliminary Objections) [1996] ICJ Rep 595 ('1996 judgment').

11 Article IX provides: '[d]isputes between the Contracting Parties relating to the interpretation, application or fulfilment of the present Convention, including those relating to the responsibility of a State for genocide or for any other acts enumerated in article III, shall be submitted to the International Court of Justice at the request of any of the parties to the dispute': Genocide Convention, opened for signature 9 December 1948, 78 UNTS 277, art IX (entered into force 12 January 1951).

12 Dragomir Djokic, Letter Dated 6 May 1002 from the Chargé D'Affaires a.i. of the Permanent Mission of Yugoslavia to the United Nations Addressed to the Secretary General, UN GAOR, $46^{\text {th }}$ sess. Annex I, 2, UN Doc.A/46/915 (1992).

13 Application for Revision of the Judgment of 11 July 1996 in the Case Concerning the Application of the Convention on the Prevention and Punishment of the Crime of Genocide (Bosnia and Herzegovina $v$ Yugoslavia) (Preliminary Objections) (Yugoslavia v Bosnia and Herzegovina) [2003] ICJ Rep 7 ('2003 judgment').

14 Statute of the International Court of Justice at International Court of Justice ("ICJ') <http://www.icjcij.org/documents/index.php?pl $=4 \& p 2=2 \& p 3=0>$ at 28 March 2008.

15 Djokic, above $\mathrm{n} 12,[18]$. 
Yugoslavia's Article 61 request inadmissible: ${ }^{16}$ 'A fact which occurs several years after a judgment has been given is not a "new" fact within the meaning of Article 61 ... irrespective of the legal consequences that such a fact may have. ${ }^{17}$ The FRY's admission to the UN in 2000, well after the 1996 judgment, cannot be considered a new fact, supporting the request for revision of the judgment. ${ }^{18}$

\section{THE JUDGMENT}

Despite the fact that the case was initially filed in 1993, hearings were not opened until 27 February 2006 and final judgment was handed down on 26 February 2007, 14 years after the initial filing. The Court's 15 judges produced a 563 page judgment containing a 171 page majority judgment, and declarations, opinions and dissenting opinions of an additional 392 pages. The Court, inter alia, came to the following conclusions:

(1) The finding of res judicata of the 1996 judgment precluded reopening of thejurisdictional question and thereby provided the Court with jurisdiction to consider the merits of the case.

(2) States can be held responsible for violating provisions of the Genocide Convention.

(3) The only genocidal acts in Bosnia were those of July 1995 at Srebrenica.

(4) The Srebrenica genocidal acts could not be attributed to Serbia.

(5) Serbia was responsible for failure to prevent and punish the Srebrenica genocide.

(6) Satisfaction was appropriate reparation.

\section{A Jurisdiction}

Serbia argued no jurisdiction on the basis that the FRY did not continue the legal personality of the SFRY, therefore making it not a party to the Genocide Convention, the Charter of the United Nations, nor the Statute of the International Court of Justice when proceedings were commenced. ${ }^{19}$ Serbia maintained that as the UN had not recognised the FRY as continuator of the SFRY, the FRY was not a member until 2000 when the newly-elected President Kosttunica applied for UN membership on behalf of the FRY. By ten to five, the Court rejected Serbia's argument, concluding that the 1996 judgment carried the force of res judicata thus precluding any reopening of the decision embodied in

16 Article 61(1) provides: '[a]n application for revision of a judgment may be made only when it is based upon the discovery of some fact of such a nature as to be a decisive factor, which fact was, when the judgment was given, unknown to the Court and also to the party claiming revision, always provided that such ignorance was not due to negligence': Statute of the International Court of Justice, art 61(1).

172003 judgment, [2003] ICJ Rep 7, [67].

18 Ibid [68].

19 Genocide case, Intemational Court of Justice, 26 February $2007<\mathrm{http} / /$ www.icjcij.org/docket/index.php?pl=3\&k=f4\&case=91\&code=bhy\&p3=4> at $26 \mathrm{March} 2008,[80]$. 
that judgment, and thereby providing jurisdiction to adjudicate through Article IX of the Genocide Convention. ${ }^{20}$ The Court noted:

The operative part of the 1996 Judgment stated ... that the Court found "that, on the basis of Article IX of the Convention on the Prevention and Punishment of the Crime of Genocide, it had jurisdiction to decide upon the dispute." That jurisdiction is established with the full weight of the court's judicial authority. For a party to assert today that, at the date the 1996 Judgment was given, the Court has no power to give it, because one of the parties can now be seen to have been unable to come before the Court is ... to call in question the force as res judicata of the operative clause of the Judgment. ${ }^{2}$

Since ... the question of a State's capacity to be a party to proceedings is a matter which precedes that of jurisdiction ratione materiae ... this finding must as a matter of construction be understood, by necessary implication, to mean that the Court at that time perceived the Respondent as being in a position to participate in cases before the Court.

Furthermore, the majority indicated it was not necessary to consider questions concerning the FRY's UN membership at the time of filing the application, or its alleged acquiescence to the 1996 judgment. ${ }^{23}$ Accordingly, the Court's judgment was final and conclusive as to the rights of the parties, thereby providing the Court with jurisdiction over the merits of the case. ${ }^{24}$

Three judges' findings on jurisdiction did not base their reasoning on res judicata. Expressing concern in re-examining jurisdiction, since previously established, Vice-President Al-Khasawneh, in his dissenting opinion, believed jurisdiction pivoted around the status of the FRY's UN membership at time of filing. The 'revelations' of UN resolutions and the FRY's subsequent application in 2000 for 'new' membership did not terminate membership, but resulted in consequential non-participation as a sanction. The SFRY never ceased membership and, coupled with the fact that membership was never terminated, that meant it retained membership despite the breakaway of other states. ${ }^{23}$ Further, the FRY through its assertions was treated as a continuer. An application for 'new' membership in 2000 could not retrospectively change the status of being a continuer between 1992 and 2000, and a successor from 2000 onwards. ${ }^{26}$

Judge Owada viewed res judicata applying to the entirety of the 1996 judgment as too broad an interpretation of the principle: what was required was determination of issues within its scope, not automatic application. The critical question was whether access had been dealt with in the 1996 judgment and thus included within the scope of res judicata. ${ }^{27}$ The present case was distinguishable

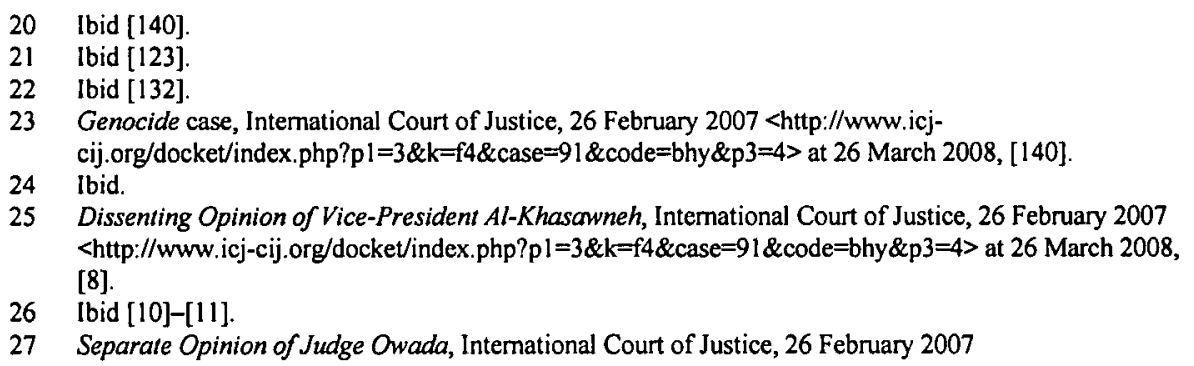

25 Dissenting Opinion of Vice-President Al-Khasowneh, International Court of Justice, 26 February 2007 $<$ http://www.icj-cij.org/docket/index.php?pl=3\&k=f4\&case=91\& code=bhy\&p3=4> at 26 March 2008, [8]. 
from the Legality of Use of Force cases ('NATO cases') ${ }^{28}$ due to temporal differences regarding respective decision-making. 2004 was the first time the Court had the opportunity to examine the FRY's position in light of all facts, unlike the legal situation surrounding the 1996 judgment. Thus access, which logically precedes jurisdiction, must have been contemplated by the Court and therefore, the judgment made a 'definitive determination' upon it as well, bringing it within the ambit of res judicata. ${ }^{29}$ 'The Court itself ... is now precluded from taking a different position at this stage that would be diametrically opposed to the one that the Court itself is deemed to have so definitely determined ...' (emphasis omitted). ${ }^{30}$

Judge Tomka was concerned that Serbia was invited to present more jurisdictional arguments; this seemed inconsistent with dismissing the 2003 revision application that found jurisdiction based on res judicata of the 1996 decision. His Excellency considered whether the FRY had access to the Court at time of filing in 1993 and noted that this was not considered in 1996. His Excellency was not convinced by the 'strained' majority reasoning that the issue was perceived through 'necessary implication'. ${ }^{31}$ Thus the Court should have considered jurisdiction de novo. Serbia not having access could be remedied, and did not preclude exercise of jurisdiction ratione personae. His Excellency distinguished the divergence from this principle in the 2004 case on the basis of Serbia's then circumstances. ${ }^{32}$ Since the FRY's claim as continuer had failed, customary ipso jure succession was explored, where successor states continue any treaty, in force at time of succession of the predecessor state, unless special circumstances existed. Through the FRY's 1992 succession it continued the SFRY's treaty obligations, meaning that Serbia had been bound by the Genocide

$<$ http://www.icj-cij.org/docket/index.php?p $1=3 \& k=f 4 \& c a s e=91 \&$ code=bhy\&p3=4> at $26 \mathrm{March} 2008$, [16].

28 Legality of Use of Force (Serbia and Montenegro v Belgium) (Preliminary Objections) [2004] ICJ Rep 279; Legality of Use of Force (Serbia and Montenegro v Canada) (Preliminary Objections) [2004] ICJ Rep 429; Legality of Use of Force (Serbia and Montenegro v France) (Preliminary Objections) [2004] ICJ Rep 575; Legality of Use of Force (Serbia and Montenegro v Germany) (Preliminary Objections) [2004] ICJ Rep 720; Legality of Use of Force (Serbia and Montenegro v Italy) (Preliminary Objections) [2004] ICJ Rep 865; Legality of Use of Force (Serbia and Montenegro v Netherlands) (Preliminary Objections) [2004] ICJ Rep 1011; Legality of Use of Force (Serbia and Montenegro v Portugal) (Preliminary Objections) [2004] ICJ Rep 1160; Legality of Use of Force (Serbia and Montenegro v United Kingdom) (Preliminary Objections) [2004] ICJ Rep 1307; Legality of Use of Force(Yugoslavia $v$ Spain) (Provisional Measures) [1999] ICJ Rep 761; Legality of Use of Force (Yugoslavia v United States of America) (Provisional Measures) [1999] ICJ Rep 916 ('NATO cases'). Based on the ambiguities of the FRY's UN membership the ICJ found that as the FRY was not a UN member the Court lacked jurisdiction to hear the claims made by Serbia and Montenegro. See Klinton Alexander, 'NATO'S Intervention in Kosovo: The Legal Case for Violating Yugoslavia's National Sovereignty in the Absence of Security Council Approval' (2000) 22 Houston Journal of International Law 403.

29 Separate Opinion of Judge Owada, International Court of Justice, 26 February 2007 <http://www.icj-cij.org/docket/index.php?pl=3\&k=f4\&case=91\&code=bhy\&p3=4> at $26 \mathrm{March} 2008$, [33]-[34].

30 Ibid [37]

31 Separate Opinion of Judge Tomka, International Court of Justice, 26 February 2007 <http://www.icj-cij.org/docket/index.php?pl=3\&k=f4\&case=91\&code=bhy\&p3=4> at 26 March 2008, [21].

32 Ibid [30]. 
Convention since 1992 and party to the Statute of the International Court of Justice, jurisdiction and access thus granted. ${ }^{33}$

Five judges believed the Court did not have jurisdiction and had difficulty applying res judicata and reconciling the NATO cases. In their joint dissenting opinion, Judges Ranjeva, Shi and Koroma voiced serious misgivings about 'necessary implications' stemming from the finding of res judicata of the 1996 decision. Reliance on res judicata allowed the Court to overlook two key issues: Serbia's UN membership, and its obligations under the Genocide Convention. Reliance on res judicata to establish ratione personae implies the Court discussed and found access in 1996, which it did not. Thus access cannot come within the ambit of res judicata. ${ }^{34}$ The finding in the NATO cases that Serbia was not a UN member did not have the force of res judicata as it was not between the same parties. However, if Serbia was not a member in 1999, then it was not in 1993 either. ${ }^{35}$ Their Excellencies viewed the decision in the NATO cases as correct in that there the Court felt bound first and foremost to examine the question of access because of its fundamental importance, and regrettable that this was not followed here. ${ }^{36}$

According to Judge Skotnikov, because the NATO cases found Yugoslavia was not a UN member at the relevant time and therefore not party to the Statute, the Court concluded Yugoslavia had no access to the Court. This created a legal reality which could not now be departed from. ${ }^{37}$ The majority on the other hand created a 'parallel reality' through applying res judicata and further, they justified their action as not being ultra vires because a finding of jurisdiction in incidental proceedings is absolute and exhaustive. It is contradictory to invite Serbia to raise jurisdictional arguments at the merits phase, when there had been a finding with res judicata force in 1996: this invitation could not have been issued if the Court felt there was no possibility of negating jurisdiction. He concluded res judicata was not absolute and exhaustive in incidental proceedings, and to view it as so sharply departs from previous approaches. ${ }^{38}$

For Judge ad hoc Kreća, in cases where jurisdiction was found at the preliminary objections stage, but later it was discovered that no such jurisdiction existed, the use of res judicata would 'commit a manifest abuse of authority' ${ }^{39}$ His Excellency noted the distinction between $j u s$ standi and jurisdiction and that having acquired one does not imply existence of the other; jus standi is a

33 Ibid [35]-[36].

34 Joint Dissenting Opinion of Judges Ranjeva, Shi and Koroma, International Court of Justice, 26 February 2007

<http://www.icj-cij.org/docket/index.php?pl=3\&k=f4\&case=91\&code=bhy\&p3=4> at 26 March 2008, [19].

35 lbid [13].

36 Ibid [17].

37 Declaration of Judge Skotnikov, International Court of Justice, 26 February 2007

<http://www.icj-cij.org/docket/index.php?pl=3\&k=f4\&case=91\&code=bhy\&p3=4> at 26 Mach 2008, 1 38 Ibid 3

39 Von Tiedemann v Polish State, Rec. TAM, I VI, 997-1003, (Polish-German Mixed Arbitral Tribunal) in Separate Opinion of Judge ad hoc Kreća, International Court of Justice, 26 February 2007 $<$ http://www.icj-cij.org/docket/index.php?pl=3\&k=f4\&case $=91 \&$ code=bhy\&p3 $=4>$ at 26 March 2008, [12]. 
precondition of jurisdiction. His Excellency held that 'necessary implication' was an attempt to force judgment by implication into the separate realm of judicial reasoning. ${ }^{40}$ The Court relied on an assumption the FRY possessed the right to appear before the Court in the 1996 judgment and the assumption acted as an element of reasoning. His Excellency disputed the legitimacy of this through comparing the function of judicial and legal assumptions finding that after the true facts were discovered the assumption should have been abandoned. ${ }^{41}$

\section{B Responsibility for Genocide}

\section{Can States Commit Genocide?}

Serbia claimed that the meaning of Article IX of the Genocide Convention is ambiguous and its drafting history showed no intention to include direct responsibility of the state. ${ }^{42}$ According to the majority, genocide, as provided for under Article II of the Genocide Convention, could apply to both individuals and states. ${ }^{43}$ '[A]s a matter of general principle, international law does not recognise criminal responsibility of the State, and the Genocide Convention does not provide a vehicle for imposing such criminal responsibility. ${ }^{44}$ International law recognises the duality of responsibility of the individual and the state. The majority saw nothing in the Genocide Convention relating to individual criminal responsibility that would displace the meaning of Articles I and III, as they impose obligations on states distinct from those obligations imposed on individuals. ${ }^{45}$

Five judges believed Article I did not make genocide a crime that states could commit, rather only individuals could commit the crime of genocide. According to Judges Shi and Koroma, a state cannot be held directly to have committed the crime of genocide, consistent with the object and purpose of the Genocide Convention, as it does not impose criminal responsibility on the state per se. ${ }^{46}$ According to the ordinary meaning of the treaty's terms, read in their context and in light of its object and purpose, the Genocide Convention is directed against individuals, not states. The responsibilities of State Parties are found in Articles $\mathrm{V}$ to VIII, and are aimed at preventing and punishing individuals who commit the crime of genocide. There was no intention that a state party should punish itself for the crime of genocide. Their Excellencies disagreed with the majority's interpretation by implication or logic of Article I as imposing upon a state the obligation not to commit genocide. Primary regard must be given to the parties' intention at the time the treaty was concluded; Article IV places the responsibility

40 Ibid [40].

41 Ibid [44]-[47].

42 Genocide case, International Court of Justice, 26 February $2007<$ http://www.icjcij.org/docket/index.php?pl $=3 \& \mathrm{k}=\mathrm{f} 4 \&$ case=91\&code=bhy\&p3=4> at $26 \mathrm{March} 2008,[176]$.

43 Ibid [179].

44 Ibid [170].

45 Ibid [174].

46 Joini Declaration of Judges Shi and Koroma, International Court of Justice, 26 February 2007 $<$ http://www.icj-cij.org/docket/index.php?pl=3\&k=f4\&case=91\&code=bhy\&p3=4> at $26 \mathrm{March} 2008$, [1]. 
for the crime on the individual. The Genocide Convention does not entitle the Court to hold a criminal trial. ${ }^{47}$

Judge Owada viewed Article I as excluding from its scope the issue of direct responsibility of a state for the commission of genocide as an international crime of the state. The Genocide Convention prevents and punishes genocide by prosecuting individuals who commit the criminal act with dolus specialis, whether acting as organs of a state or otherwise. Article I outlines that genocide, whenever perpetrated, is a crime under international law and lays down the legal obligation upon the contracting parties to prevent and punish genocide. It is on the basis of Article IX, however, that parties have substantive obligations under the Genocide Convention. Therefore the Court can examine the issue of Serbia's state responsibility arising out of alleged acts of genocide committed by individuals and entities whose actions can be attributed to Serbia under the law of state responsibility. ${ }^{48}$

Judge Tomka also believed that Article I makes genocide a crime of individuals, and not the state. Article I only makes state parties obligated to prevent the commission of the crime and to punish the perpetrators. ${ }^{49}$ Like Judge Owada, his Excellency believed that the Court could determine international responsibility of a state for genocide on the basis of attribution to the state of the act perpetrated by a person. This Court, however, is not the appropriate forum in which to make a finding that genocide was committed. ${ }^{50}$ Judge Skotnikov did not believe in the existence of state criminal responsibility, but rather that state responsibility could be imputed for certain acts. ${ }^{51}$ Furthermore, the Court cannot establish individual criminal responsibility for genocide committed by persons capable of engaging a state's responsibility since it lacks criminal jurisdiction. ${ }^{52}$

\section{Was Genocide Committed?}

In determining the nature and existence of the acts alleged, the Court acknowledged the findings of the ICTY that it relied on heavily to establish the factual background. Relevant institutions, organisations and groups in operation

47 Ibid [4].

48 Separate Opinion of Judge Owada, International Court of Justice, 26 February 2007 $<$ http://www.icj-cij.org/docket/index.php?pl=3\&k=f4\&case=91 \&code $=$ bhy\&p3=4> at $26 \mathrm{March} 2008$, [73].

49 Separate Opinion of Judge Tomka, International Court of Justice, 26 February 2007 $<$ http://www.icj-cij.org/docket/index.php?pl=3\&k=f4\&case=91\&code=bhy\&p3=4> at 26 March 2008 , $[60]$.

50 Ibid [61].

51 Declaration of Judge Skotnikov, International Court of Justice, 26 February 2007 $<$ http://www.icj-cij.org/docket/index.php?pl=3\&k=f4\&case=91\&code=bhy\&p3=4> at $26 \mathrm{March} 2008$, $4-5$.

$52 \quad$ Ibid 6. 
in Bosnia ${ }^{53}$ were critical in establishing Serbia's responsibility for genocide, as Bosnia alleged close political and financial ties existing between the Serbian government and authorities of the Republika Sprska, and regarding administration and control of the Republika Sprska's army ('VRS'). ${ }^{54}$ Allegedly Serbia, under the guise of protecting the Bosnian-Serb population, "conceived and shared with [the VRS] a vision of a "Greater Serbia" in pursuit of which it supported those responsible for the allegedly genocidal acts'. ${ }^{55}$ The allegation was founded on 'Strategic Goals' articulated by President Karadžić on 12 May 1992 and on consistent conduct of Serb military and paramilitary forces showing an overall specific genocidal intent (dolus specialis) vis-à-vis non-Serb Bosnians. ${ }^{56}$ The majority found Serbia was providing 'considerable financial and military support' to the Republika Sprska and 'had it withdrawn that support, this would have greatly constrained the options that were available to the Republika Sprska authorities'. ${ }^{57}$

To determine whether genocide had been committed, the Court considered if the protected group, Bosnian Muslims, had been subject to any conditions set out in Article II of the Genocide Convention. Were any of the following acts committed with intent to destroy, in whole or in part, the protected group?

(a) Killing members of the group;

(b) Causing serious bodily or mental harm to members of the group;

(c) Deliberately inflicting on the group conditions of life calculated to bring about its physical destruction in whole or in part;

(d) Imposing measures intended to prevent births within the group;

(e) Forcibly transferring children of the group to another group. ${ }^{58}$

In considering whether there had been killings of members of the group, ${ }^{59}$ the majority stated '[Serbia] does not deny that crimes were committed during the

53 On 15 October 1991 Bosnia declared independence, as did the Republic of the Serb People of Bosnia on 9 January 1992 (later called Republika Sprska). The following armed units were active in hostilities: Yugoslav People's Army ('JNA'), subsequently Yugoslav Army ('VJ'); volunteer units supported by the JNA and VJ, and the FRY's Ministry of the Interior ('MOU'); municipal Bosnian-Serb Territorial Defence detachments; and police forces of the Bosnian-Serb Ministry of Interior. On 15 April 1992 the Bosnian Government established the Army of the Republic of Bosnia merging several non-official forces including a number of paramilitary defence groups including the Green Berets and the Patriotic League, the military wing of the Muslim Party of Democratic Action: Genocide case, International Court of Justice, 26 February 2007

<http://www.icj-cij.org/docket/index.php?p $1=3 \& k=f 4 \&$ case $=91 \&$ code $=$ bhy \&p3 $3=4>$ at 26 March 2008, [235]-[236].

54 Ibid [237]-[238].

55 Ibid [237].

56 Ibid [237].

57 Ibid [24l].

58 Genocide Convention, opened for signature 9 December 1948, 78 UNTS 277, art II (entered into force 12 January 1951).

59 Evidence was examined to determine whether killings of members of the protected group occurred in the principal Bosnian areas and the various detention camps: Susica camp; Foča Karazneno-Popravni camp; Omarska camp; Keraterm camp; Trmopolje camp; Manjaca camp (Banja Luka): above n 53, [262]-[271], [305]-[310]. 
siege of Sarajevo, crimes that "could certainly be characterized as war crimes and even crime against humanity", but it does not accept that there was a strategy of targeting civilians, ${ }^{60}$ Based on overwhelming evidence, the majority concluded that massive killings had occurred in specific areas and detention camps during the conflict and the victims were in large majority members of the group. ${ }^{6}$ Despite this, the dolus specialis requirement could not be met as the killings were not conducted with specific genocidal intent. ${ }^{62}$

The Srebrenica killings were examined separately. In examining intent, the majority discussed the Trial Chamber of the ICTY's finding in Prosecutor $v$ Radislav Krstic where 'following the takeover of Srebrenica in July 1995, the Bosnian Serbs devised and implemented a plan to execute as many as possible of the military-aged Bosnian Muslim men present in the enclave'. ${ }^{63}$ All executions systematically targeted Bosnian Muslim men of military age, regardless of civilian or military status. ${ }^{64}$ This conclusion was confirmed by the ICTY Appeals Chamber; the loss of one fifth of Srebrenica's overall population 'would inevitably result in the physical disappearance of the Bosnian Muslim population at Srebrenica'. ${ }^{65}$ The majority found the dolus specialis 'was not established until after the change in the military objective and after the takeover of Srebrenica on or about 12 or $13 \mathrm{July}{ }^{, 66}$ They concluded genocidal acts falling within the ambit of Articles II(a) and (b), and with the specific intent to destroy in part the group of Bosnian Muslims, were committed at Srebrenica by members of the VRS from about 13 July 1995 . $^{67}$

Regarding 'causing serious bodily or mental harm to members of the group', even though it was 'established by fully conclusive evidence that members of the group were systematically subjected to massive mistreatment, beatings, rape and torture during the conflict ... and, in particular, in the detention camps', a specific intent to destroy the group, in whole or in part, was absent. ${ }^{68}$ Furthermore, regarding 'deliberately inflicting on the group conditions of life calculated to bring about its physical destruction in whole or in part', though there was 'convincing and persuasive evidence that terrible conditions were inflicted upon detainees of the camps', again the Court was of the view that the dolus specialis was absent. ${ }^{69}$ Regarding 'imposing measures intended to prevent births within the group' and 'forcibly transferring children of the group to another group', it was found that there was insufficient evidence to establish that such acts had occurred. ${ }^{70}$

60 Ibid [249].

61 Ibid [276].

62 Ibid [277].

63 (Judgment), [T-98-33-T, 2 August 2001, [87] (ICTY Trial Chamber) ('Krstić') in ibid [292].

64 Krstic (Judgment), IT-98-33-T, 2 August 2001, [546] (ICTY Trial Chamber) in ibid.

65 Prosecutor v Radislav Krstic (Appeals Chamber Judgment), IT-98-33-A, 19 April 2004, [28-33] (ICTY Appeals Chamber) ('Krstic Appeal') in ibid [293].

66 Ibid [295].

67 Ibid [297].

68 Ibid [319].

69 lbid [354].

70 Ibid [361], [367]. 
Bosnia argued that despite absence of an official statement of aims reflecting genocidal intent, the dolus specialis of those directing the events 'is clear from the consistency of practices, particularly in the camps, showing that there was a pattern of acts committed "within an organized institutional framework". ${ }^{71}$ The majority viewed the Decision on Strategic Goals as providing for population transfers but not evidence of a genocidal dolus specialis. ${ }^{72}$ The majority also rejected Bosnia's further argument that 'the pattern of the atrocities committed across many communities, over a lengthy period and focussed [sic] on Bosnian Muslims and also Croatians, demonstrates the necessary intent'. ${ }^{75}$

In his dissenting opinion, Vice-President Al-Khasawneh found that Serbia should have been found responsible as principal actor and the Court should have inferred genocidal intent from the consistent pattern of conduct. In Krstic Appeal, the Appeals Chamber held that ethnic cleansing can be evidence of the mens rea of genocide and that intent may be inferred from the crime's factual circumstances. The majority found population transfer was one way of achieving the Bosnian Serbs' strategic goals, however the Court should have also found those goals were being achieved through massive killings of members of the protected group. ${ }^{74}$ His Excellency indicated regret that the Court did not more closely consider the consistent recent jurisprudence of the international criminal tribunals on the permissibility, and even the necessity, of relying on facts and circumstances from which to infer dolus specialis. ${ }^{75}$

On the other hand, Judge ad hoc Kreća believed intent should not be inferred from acts, and the law applied by the ICTY is different from that to be applied in the present case. The ICTY Trial Chamber erred in inferring genocidal intent from facts. ${ }^{76}$ Intent may only be inferred if it satisfies quantitative and qualitative standards. When looking at qualitative conditions, the inferential element must consist of acts capable of objectively producing genocidal effects or being constitutive of genocide. 'Deduction of genocidal intent from acts which per se cannot have genocidal effects ... cannot be considered as acts in terms of Article II of the Convention. ${ }^{, 77}$ The law applied by the ICTY regarding genocide cannot be considered the same as the law of genocide under the Genocide Convention. Judge Skotinkov also had difficulties reconciling Krstić, where genocidal intent may be drawn even where the individuals to whom the intent is attributable are not precisely identified. His Excellency concluded that the finding of the Srebrenica massacre as genocide was not sufficiently established. ${ }^{78}$

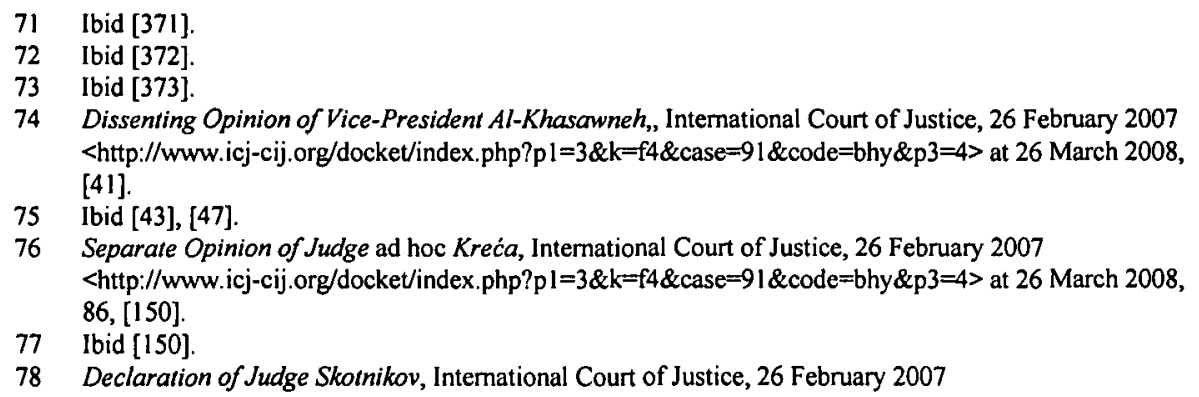




\section{Can the Genocide be Attributed to Serbia?}

The Court examined whether the Srebrenica genocidal acts could be attributed to Serbia. By thirteen to two the Court found that under rules of state responsibility, responsibility could not be attributed to Serbia ${ }^{79}$ through its organs or persons whose acts engage responsibility. ${ }^{80}$

The majority first considered whether there was conduct of state organs directly attributable to the State. ${ }^{81}$ Bosnia claimed 'all officers in the VRS, including General Ratko Mladić, commander of the Bosnian Serb forces, remained under FRY military administration ... up to 2002' and argued they were 'de jure organs of the FRY' ${ }^{82}$ The majority found ' $[t]$ he functions of the VRS officers, including General Mladić, were however to act on behalf of Bosnian Serb authorities, in particular the Republika Srpska, not on behalf of the FRY; they exercised elements of the public authority of the Republika Srpska'. ${ }^{83}$ The Srebrenica genocide could not be attributed to Serbia as there was no evidence the genocide had been committed by persons or entities ranking as organs of the Serbian government ${ }^{84}$ Furthermore, Bosnia alleged the Scorpions were a state organ of the FRY. ${ }^{85}$ In referring to the Court's jurisprudence, the majority stated that

persons, groups of persons or entities may, for purposes of international responsibility, be equated with State organs even if that status does not follow from internal law, provided that in fact the persons, groups or entities act in 'complete dependence' on the State, of which they are ultimately merely the instrument.

According to the majority therefore Serbia was not responsible for the conduct of the Scorpions as it could not be proved the Scorpions were at the relevant time in mid-1995 a de jure ${ }^{87}$ or de facto ${ }^{88}$ organ of the FRY.

<http://www.icj-cij.org/docket/index.php?pl=3\&k=f4\&case=91\&code=bhy\&p3=4> at 26 Mach 2008, 8-

79 In establishing whether the genocidal acts could be attributed to Serbia the majority relied on the customary international law of state responsibility as provided in the International Law Commission's, 'Articles on the Responsibility of States for Internationally Wrongful Act' in the Report of the International Law Commission, Fify-third Session (23 April-I June and 2 July-10 August 2001), UN GAOR, 56 $6^{\text {th }}$ sess, Supp No 10, 68-74, UN Doc A/56/10 (2001) ('ILC articles').

80 Genocide case, Intemational Court of Justice, 26 February $2007<\mathrm{http}: / / \mathrm{www}$.icjcij.org/docket/index.php?pl $=3 \& \mathrm{k}=\mathrm{f} 4 \&$ case $=91 \&$ code $=$ bhy\&p3 $=4>$ at $26 \mathrm{March} 2008,[471]$.

81 Article 4 of the ILC articles, Conduct of Organs of a State, provides that

'(1) The conduct of any State organ shall be considered an act of that State under international law, whether the organ exercises legislative, executive, judicial or any other functions, whatever position it holds in the organization of the State, and whatever its character as an organ of the central Government or of a territorial unit of the State. (2) An organ includes any person or entity which has that status in accordance with the internal law of the State': ILC articles, above n 79, 84 .

82 Genocide case, International Court of Justice, 26 February $2007<\mathrm{http}: / / \mathrm{www}$.icjcij.org/docket/index.php?pl=3\&k=f4\&case=91\&code=bhy\&p3=4> at 26 March 2008, [387].

83 Ibid [388]

84 Ibid [395]

85 The Scorpions were a paramilitary militia that Bosnia alleged was the 'MUP of Serbia' and 'a unit of Ministry of Interiors of Serbia': ibid [389].

86 Ibid [392]

87 Ibid [389]

88 Ibid [394] 
Nor, according to the majority, were the massacres committed on or under the FRY's instructions, or direction and control. ${ }^{89}$ The majority found Serbia not responsible under international law, as no factual basis had been established for finding that Serbia had the requisite direction or control over the operations in the course of which the massacres were perpetrated. ${ }^{90}$ In reaching this conclusion the majority relied on the 'effective control' test as provided by the ICJ in Military and Paramilitary Activities in and Against Nicaragua (Nicaraguav United States of America) ${ }^{91}$ and not the 'overall control' test of the ICTY Appeals Chamber in Prosecutor $v$ Miroslav Tadic ${ }^{92}$ thereby rejecting Bosnia's claim of overall control exercised by the FRY over the Bosnian Serbs. ${ }^{93}$

According to Vice-President Al-Khasawneh, however, the Court should have applied the 'overall control' test as 'when the shared objective is the commission of international crimes, to require both control over the non-State actors and the specific operations in the context of which international crimes were committed is too high a threshold'. ${ }^{44}$ Regarding Belgrade's knowledge of activities at Srebrenica, '[t]here can be no doubt that President Milošević was fully appraised of General Mladic's (and the Bosnian Serb army's) activities in Srebrenica throughout the takeover and massacres'.95 His Excellency refers to the majority's statement '[f]urthermore, the Court notes that in any event the act of an organ placed by a State at the disposal of another public authority shall not be considered an act of that State if the organ was acting on behalf of the public authority at whose disposal it had been placed'. ${ }^{96}$ There is no evidence that the Scorpions were placed at the disposal of another public authority. A factual interpretation was needed, namely the Scorpions were controlled by Serbia as they were described as 'MUP of Serbia' or 'a unit of Ministry of Interiors of Serbia'. ${ }^{97}$

The Vice-President believed the Court should have relied on statements of the new Serbian government because their intent was to acknowledge the previous

89 Article 8 of the ILC articles, Conduct Directed or Controlled by a State, provides that "[t]he conduct of a person or group of persons shall be considered an act of a State under international law if the person or group of persons is in fact acting on the instructions of, or under the direction and control of, that State in carrying out the conduct': ILC articles, above n 79, 103.

90 Genocide case, International Court of Justice, 26 February $2007<$ http://www.icjcij.org/docket/index.php?pl $=3 \& \mathrm{k}=\mathrm{f} 4 \&$ case $=91 \&$ code=bhy \&p3=4> at $26 \mathrm{March} 2008,[412]$

91 (Merits) [1986] ICJ Rep 14, 62 ('Nicaragua').

92 (Appeals Chamber Judgment), IT-94-1-A, 15 July 1999, [122] (ICTY Appeals Chamber) ('Tadić).

93 Genocide case, International Court of Justice, 26 February $2007<$ http://www.icjcij.org/docket/index.php?pl=3\&k=f4\&case=91 \&code=bhy\&p3=4> at 26 March 2008, 402, 404.

94 Dissenting Opinion of Vice-President Al-Khasawneh, International Court of Justice, 26 February 2007 <http://www.icj-cij.org/docket/index.php?pl=3\&k=f4\&case=91\&code=bhy\&p3=4> at $26 \mathrm{March} 2008$, [39].

95 lbid [51]

96 Genocide case, Intemational Court of Justice, 26 February $2007<\mathrm{http}: / / \mathrm{www}$.icjcij.org/docket/index.php?pl $=3 \& \mathrm{k}=\mathrm{f} 4 \&$ case $=91 \&$ code $=$ bhy \&p3=4> at $26 \mathrm{March} 2008$, [389]

97 Dissenting Opinion of Vice-President Al-Khasawneh, International Court of Justice, 26 February 2007 $<$ http://www. icj-cij.org/docket/index.php?pl=3\&k=f4\&case=91\&code=bhy\&p3=4> at 26 March 2008, $[53]-[55]$ 
regime's responsibility and 'admit' past wrongs. ${ }^{98}$ Serbia's unilateral statement was more than political: 'declarations made ... by highly placed government officials can have binding legal consequences'. ${ }^{99}$ The following statement amounted to an admission of the responsibility of President Miloševićs regime for the Srebrenica genocide:

Given the continuity of State responsibility, despite the change in régime, th[e] statement [by the Serbian Council of Ministers] acknowledge[s] the facts or conduct unfavourable to the State making the statement, and on the basis of Nicaragua thereby amounts to a form of admission, or ... evidence of the truth of the facts it asserts.

Further, by thirteen to two the Court found that Serbia had not conspired to commit genocide, nor incited the commission of genocide, under the Genocide Convention. ${ }^{101}$ By eleven to four, the Court found Serbia not complicit in genocide under the Genocide Convention. ${ }^{102}$ Regarding complicity, Judge Keith assessed President Milošević's relationship with General Mladić and concluded that Milošević must have known the VRS had formed the intent to destroy in part the protected group thereby making Serbia complicit in genocide. For complicity to be established, Serbia must have had knowledge of the principal perpetrator's genocidal intent (but need not share that intent) and with that knowledge have provided aid and assistance to the perpetrator. ${ }^{103}$

\section{Did Serbia Fail to Prevent and Punish Genocide?}

By a twelve to three majority the Court found that Serbia breached its obligation to prevent genocide. According to the majority the obligation is one of conduct and not one of result and states must 'employ all means reasonably available to them, so as to prevent genocide as far as possible' ${ }^{104}$

In view of their undeniable influence and of the information, voicing serious concern, in their possession, the Yugoslav federal authorities should, in the view of the Court, have made the best efforts within their power to try and prevent the tragic events then taking shape, whose scale, though it could not have been foreseen with certainty, might at least have been surmised. ... [F] held responsible for breaching its obligation of prevention, it does not need to be proven that the State concerned definitely had the power to prevent the genocide; it is sufficient that it had the means to do so and that it manifestly refrained from using them.

98 Following the fall of the Milosevic regime, the new Serbian Government expressed condemnation of the Srebrenica crimes and demanded the criminal responsibility of all who had committed war crimes: ibid [56], [58].

99 Ibid [57]

100 Ibid [60] (emphasis omitted)

101 Genocide case, International Court of Justice, 26 February $2007<\mathrm{http}: / /$ www.icjcij.org/docket/index.php?pl=3\&k=f4\&case=91\&code=bhy\&p3=4> at $26 \mathrm{March} 2008,[471]$.

102 lbid.

103 Declaration of Judge Keith, International Court of Justice, 26 February $2007<$ http://www.icjcij.org/docket/index.php?pl $=3 \& \mathrm{k}=\mathrm{f} 4 \&$ case $=91 \&$ code=bhy\&p3=4> at $26 \mathrm{March} 2008,[7]$.

104 Genocide case, International Court of Justice, 26 February $2007<$ http://www.icjcij.org/docket/index.php?pl=3\&k=f4\&case=91\&code=bhy\&p3=4> at $26 \mathrm{March} 2008,[430]$.

105 [bid [438]. 
For the majority, the FRY 'was in position of influence, over the Bosnian Serbs ... unlike that of any of the other States parties to the Genocide Convention'. ${ }^{106}$ It 'could hardly have been unaware of the serious risk of [genocide] once the VRS forces had decided to occupy the Srebrenica enclave'. ${ }^{107}$ It was not shown Serbia 'took any initiative to prevent what happened', the inference being 'that the organs of the Respondent did nothing to prevent the Srebrenica massacres'. ${ }^{108}$

Judges Shi and Koroma agreed that, to be consistent with the relevant Security Council resolutions, Serbia should have attempted to prevent the July 1995 Srebrenica genocide. The Security Council resolutions should have supported this finding, instead of the various hypotheses put forward in the judgment. A breach of an obligation to prevent requires identification of a "clear missed moment of opportunity to act' and in Security Council Resolution 819 (16 April 1993) the Security Council noted that the FRY should take all measures within its power to prevent the commission of genocide. The Security Council's decision with respect to 'Srebrenica and its surroundings', together with its concerns about war crimes and the deteriorating humanitarian situation in Srebrenica, suggests that some real opportunities had presented themselves for the Bosnian-Serb leadership to have acted to try to prevent genocide. ${ }^{109}$ ' $\mathrm{Mr}$ Milošević, even though it has not been proven that he had effective control over the Bosnian Serb leadership, could and should have exerted whatever pressure he had at his disposal given the humanitarian directives concerning Srebrenica ...' ${ }^{\prime 10}$

On the other hand, three judges did not believe that Serbia breached any preventive obligation. According to Judge Tomka, the duty of states to prevent genocide can be fulfilled if a state exercises control over certain persons in their activities abroad. Article I places an obligation on the state 'to prevent genocide outside its territory to the extent that it exercises jurisdiction outside its territory, or exercises control over certain persons in their activities abroad'."11 '[I]t has not been established that [the FRY] exercised jurisdiction in the areas surrounding Srebrenica ... nor that it exercised control over the perpetrators who conducted the killings' and further, the FRY did not know in advance of the plan to execute as many of the military aged Bosnian Muslims as possible. ${ }^{112}$ Judge Skotnikov believed the Court relied on a 'politically appealing, but legally vague ... concept of a duty to prevent with the element of control being replaced with a highly

106 Ibid [434]

107 Ibid [436].

108 Ibid [438]

109 Joint Declaration of Judges Shi and Koroma, International Court of Justice, 26 February 2007

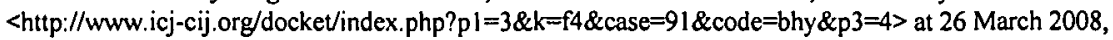
[6]

110 Joint Declaration of Judges Shi and Koroma, International Court of Justice, 26 February 2007 <http://www.icj-cij.org/docket/index.php?pl=3\&k=f4\&case=91\&code=bhy\&p3=4> at $26 \mathrm{March} 2008$, [7].

111 Separate Opinion of Judge Tomka, International Court of Justice, 26 February $2007<\mathrm{http}: / / \mathrm{www}$.icjcij.org/docket/index.php?pl $=3 \& \mathrm{k}=\mathrm{f} 4 \&$ case $=91 \& \operatorname{code}=$ bhy $\& \mathrm{p} 3=4>$ at $26 \mathrm{March} 2008,[67]$.

112 Ibid [68]. 
subjective notion of influence'. The Court should not have interpreted the duty to prevent as a duty of conduct, but rather as a duty of result. ${ }^{113}$

Judge ad hoc Kreća also believed Serbia had not breached any preventive obligation and distinguished the duty to prevent in legal terms from preventive measures defined by the Genocide Convention. Breach of the legal duty is dealt with in terms of criminal law, whereas breach of a duty to undertake the preventive measures stipulated is equivalent to a treaty violation. ${ }^{114}$ His Excellency believed the argument of 'position of influence' confuses the notions of 'influence' and 'power' and their effects in the area of prevention of genocide. 'Influence' is not a means of preventing genocide; it requires a longer time than the duration of the Srebrenica operation. ${ }^{115}$ As to the argument concerning awareness of the general risk of genocide, in civil wars the risk of ethnically motivated crimes, including genocide, is always high and serious. His Excellency believed that the argument that Serbia had not taken any initiative to prevent shows both legal and factual difficulties. Factually, it is unclear how President Milošević's warning to President Karadžić, of the risk of a massacre at Srebrenica does not represent fulfilment of the duty to act, as such a warning was the only possible preventative action where the risk of genocide arose in another state's territory. Legally, the element of causality is missing, as it has not been shown that the alleged failure to act caused the massacre. ${ }^{116}$

By fourteen to one, the Court found that Serbia breached its obligation to punish genocide by violating its duty to cooperate with the ICTY in its failure to transfer General Mladić, accused of genocide and complicity in genocide, to the ICTY. ${ }^{117}$

This failure constitutes a violation by the Respondent of its duties as a party to the Dayton agreement, and as a Member of the United Nations, and accordingly a violation of its obligations under Article VI of the Genocide Convention ... One of those requirements is that the State whose responsibility is in issue must have 'accepted [the] jurisdiction' of that 'international penal tribunal'; the Court thus finds that the Respondent was under a duty to co-operate with the tribunal concerned pursuant to international instruments other than the Convention, and failed in that duty.

Judge Skotinkov supported the finding that Serbia failed to do everything in its power to apprehend General Mladić. Further, the FRY authorities did not act on the Court's orders as they should have and if they had, then 'this could have had

113 Declaration of Judge Skotnikov, International Court of Justice, 26 February 2007 $<\mathrm{http}: / \mathrm{www}$.icj-cij.org/docket $/$ index.php?pl $=3 \& \mathrm{k}=\mathrm{f} 4 \& \mathrm{case}=91 \& \mathrm{code}=$ bhy \&p3=4> at $26 \mathrm{March} 2008$, 10.

114 Separate Opinion of Judge ad hoc Kreca, International Court of Justice, 26 February 2007 $<h t t p: / / w w w . i c j-c i j . o r g / d o c k e t / i n d e x . p h p ? p l=3 \& k=f 4 \&$ case $=91 \&$ code $=$ bhy \&p3 $=4>$ at 26 March 2008, [113].

115 Ibid [123].

116 Ibid.

117 Genocide case, International Court of Justice, 26 February $2007<\mathrm{http}$ ://www.icjcij.org/docket/index.php?pl $=3 \& \mathrm{k}=\mathrm{f} 4 \&$ case $=91 \& \operatorname{code}=$ bhy \&p3 $=4>$ at $26 \mathrm{March} 2008$, [448]

118 Ibid [449]. 
an effect of averting many of the atrocities other than genocide'. ${ }^{119}$ Serbia must cooperate with the ICTY in respect of individuals accused of genocide. ${ }^{120}$

Judge ad hoc Kreća, however, distinguished the duty to punish from the duty to institute proceedings against persons accused of genocide and found that:

To charge the Respondent with lack of cooperation with the ICTY on the basis of the fact that one of the indicted persons has not been arrested, and in the absence of credible evidence that he is on the Respondent's territory, runs counter to the principle that negative facts are not subject to being proved in the judicial proceedings ... I am of the opinion that a State that delivered to the ICTY in the described way 37 indicted individuals, including almost the complete political and military leadership, could hardly be accused of lack of cooperation in terms of a proper judicial reasoning. ${ }^{121}$

Further, by thirteen to two the Court found that Serbia failed to comply with provisional measures ordered by the Court as it failed to take all measures within its power to prevent genocide. ${ }^{122}$ By fourteen to one Serbia was required to immediately comply with its obligations to punish genocidal acts and to transfer individuals to the ICTY. ${ }^{123}$

\section{Reparations}

By thirteen to two the Court held that finding Serbia breached obligations to prevent and punish genocide constituted appropriate satisfaction and that compensation, or a direction to provide assurances and guarantees of nonrepetition were not appropriate in the present case. ${ }^{124}$ As restitution was not possible, it was inappropriate to hold Serbia responsible for restitutio in integrum. Whilst Bosnia sought compensation, the Court concluded that its anticipation extended beyond the single instance of genocide found and the finding Serbia breached its obligations of prevention and punishment only. ${ }^{125}$ Even though the Court's findings limited Bosnia's claim, a claim for damages was legitimate.

For the majority, the possibility of symbolic financial compensation required a 'sufficiently direct and certain causal nexus between the wrongful act ... and the injury suffered by [Bosnia], consisting of all damage of any type, material or

119 Declaration of Judge Skotnikov, International Court of Justice, 26 February 2007 <http://www.icj-cij.org/docket/index.php?pl=3\&k=f4\&case=91 \&code=bhy\&p3=4>at 26 March 2008, 10 .

120 Ibid 11.

121 Separate Opinion of Judge ad hoc Kreća, International Court of Justice, 26 February 2007 $<\mathrm{http}: / / \mathrm{www}$.icj-cij.org/docket/index.php?pl=3\&k=f4\&case=91 \& code=bhy\&p3=4> at 26 March 2008, [130].

122 Genocide case, International Court of Justice, 26 February $2007<$ http://www.icjcij.org/docket $/$ index.php?pl $=3 \& \mathrm{k}=\mathrm{f} 4 \&$ case $=91 \&$ code $=$ bhy $\& \mathrm{p} 3=4>$ at $26 \mathrm{March} 2008,[471]$.

123 Ibid.

124 Genocide case, International Court of Justice, 26 February $2007<\mathrm{http}: / / \mathrm{www}$.icjcij.org/docket/index.php?pl $=3 \& \mathrm{k}=\mathrm{f} 4 \&$ case $=91 \& \operatorname{code}=$ bhy \&p3=4> at $26 \mathrm{March} 2008,[469]$.

125 Ibid [64(r)]. Serbia breached the Convention through inaction to prevent genocide, rather than actual genocide or complicity to it: ibid [450]. Bosnia claimed Serbia was obliged to pay both in its own right and as parens patriae for its citizens and claimed damages as reparations in relation to personal and property injury as well as to the Bosnian economy and environment. 
moral' ${ }^{126}$ The Court had to be satisfied that the Srebrenica genocide would have been averted if Serbia had acted in compliance with its legal obligations. Reverting back to the factual conclusions the majority was not satisfied of this. No nexus could be established and hence the. Court held that 'financial compensation is not the appropriate form of reparation for the breach of the obligation to prevent genocide'. ${ }^{27}$ Satisfaction was the appropriate form of reparation and declaration of Serbia's past and continuing violations of international obligations constituted satisfaction. ${ }^{128}$

Judges Shi and Koroma relied on the principle that the ICJ cannot impose payment of damages on states. During negotiations of the Genocide Convention the forum rejected a proposed amendment that if an individual was acting on behalf of the state the ICJ could issue orders for cessation and damages. The Convention does not entitle the Court to hold a criminal trial, nor impose on the State an obligation to pay damages or to provide for them in domestic legislation. ${ }^{129}$ Accordingly, the focus of the Convention is on the punishment of genocide and any extension in responsibility beyond the criminal field is unsupported. ${ }^{130}$

Judge ad hoc Kreća believed responsibility under Article IX of the Genocide Convention did not contain any components of civil responsibility, reparation or compensation. While Article IX's travaux préparatoires mention civil responsibility, this is not enough to find its existence, contrary to the Genocide Convention's provisions. ${ }^{131}$ Judge Tomka viewed the Convention as restricting findings to criminal responsibility, thus also excluding states' civil responsibility. ${ }^{132}$ For Judge Skotnikov, when a state acknowledges responsibility for a breach of the Genocide Convention, the Court does not need to establish whether genocide occurred and may proceed to the reparations issues. But Judge Skotnikov could not find the Srebrenica massacre could be classified as genocide. ${ }^{133}$

On the other hand, Vice-President Al-Khasawneh believed that the Court's findings in operative clauses five and seven were not appropriate satisfaction. The majority's approach was incorrect as it enabled reaching conclusions that were contradictory to the facts, absolving Serbia of responsibility (except for the

126 Ibid [462]

127 Ibid.

128 UK v Albania (Corfu Channel Case) [1949] ICJ Rep, 35 ('Corfu Channel Case') in ibid [463]

129 Joint Declaration of Judges Shi and Koroma, International Court of Justice, 26 February 2007 <http://www.icj-cij.org/docket/index.php?pl=3\&k=f4\&case=91 \&code=bhy\&p3 $=4>$ at 26 March 2008, [4].

130 Ibid.

131 Separate Opinion of Judge ad hoc Kreća, International Court of Justice, 26 February 2007 $<$ http://www.icj-cij.org/docket/index.php?pl=3\&k=f4\&case=91\&code=bhy\&p3=4> at 26 March 2008, [131], [135].

132 Separate Opinion of Judge Tomka, International Court of Justice, 26 February 2007 $<$ http://www.icj-cij.org/docket/index.php?pl=3\&k=f4\&case=91\&code=bhy\&p3=4> at $26 \mathrm{March} 2008$, [61].

133 Declaration of Judge Skotnikov, International Court of Justice, 26 February 2007 $<$ http://www.icj-cij.org/docket/index.php?pl=3\&k=f4\&case=91 \&code=bhy\&p3=4> at $26 \mathrm{March} 2008$, [7], [9]. 
duty to prevent/punish). As Serbia should have been held responsible for genocide as principal and accomplice, the findings in operative clause five and seven did not constitute appropriate satisfaction. There was an admission of responsibility for the acts in Srebrenica by the Serbian Council of Ministers, which amounted to genocide. ${ }^{134}$ If the Court had considered the issues using 'more appropriate methods' there would have been more positive findings regarding Serbia's international responsibility. ${ }^{135}$

Regarding guarantees and assurances of non-repetition of Serbia's substantiated violations, the majority concluded that a declaration of satisfaction was sufficient. ${ }^{136}$ Finally, the decision that financial compensation was not appropriate was extended beyond breach of the duty to prevent and punish genocide: it was also held to be inappropriate as a form of symbolic reparation and in relation to the failure to comply with the Provisional Measures of 8 April and 13 September $1993 .{ }^{137}$

\section{COMMENT}

The judgment in the Genocide case reflects an outcome not polarised with clear 'winners' and 'losers'. President Higgins noted the decision overall did not completely satisfy either side, but stressed 'that does not mean, of course, that the court has been seeking a political compromise'. ${ }^{138}$ According to Professor Shaw the judgment avoided a verdict that would have provoked further political conflict inside Serbia. ${ }^{139}$ The Court opted for a 'safe' decision as 'bold decisions have awkward repercussions' ${ }^{140}$ Despite this the decision has resulted in divided opinion amongst Bosnians and Serbs.

The Court's conclusion has angered many Bosnians, who view the judgment as defeat and as undermining their suffering and the loss of over 7000 lives. ${ }^{141}$ On the other hand, in Serbia the judgment was positively viewed; Serbia was not held responsible for the more serious and substantial crime of genocide nor for

134 Dissenting Opinion of Vice-President Al-Khascwneh, Intemational Court of Justice, 26 February 2007 $<$ http://www.icj-cij.org/docket/index.php?pl=3\&k=f4\&case=91 \&code=bhy\&p3=4> at 26 March 2008 , [61].

135 Ibid [62].

136 Genocide case, Intemational Court of Justice, 26 February $2007<$ http://www.icjcij.org/docket/index.php?pl=3\&k=f4\&case $=91 \&$ code=bhy \&p3=4> at $26 \mathrm{March} 2008,[466]$.

137 Application of the Convention on the Prevention and Punishment of the Crime of Genocide (Bosnia and Herzegovina v Yugoslavia (Serbia and Montenegro) (Request for the Indication of Provisional Measures) [1993] ICJ Rep 3, 24, [52A(1)]-[51A(2)]. The massacre at Srebrenica took place in 1995, thereby breaching the Court's 1993 provisional measures.

138 Marlise Simons, 'Court Declares Bosnia Killings Were Genocide', New York Times (New York City), 27 February 2007, 1.

139 Selcuk Gultasli, Shaw: ICJ's Serbian Genocide Verdict Does Not Improve the Standing of the Court (2007) Today's Zaman <http://www.todayszaman.com/tz-web/detaylar.do?load=detay\&link=104995> at 26 March 2008.

140 Luban compares the decision in Nicaragua where the United States was held responsible for the acts of Contras, resulting in the United States pulling out of the ICJ: David Luban, Timid Justice: The ICJ Should Have Been Harder on Serbia (2007) Slate Magazine <http://slate.com/id/2160835> at 26 March 2008.

141 Nicholas Wood, 'Bosnian Muslims View Ruling As Another Defeat', New York Times (New York), 27 February 2007, 6. 
complicity, but rather obligations to prevent and cooperate. Thus Serbia has not been further internationally isolated, "it is clear now that not all Serbs did what was done in Srebrenica'. ${ }^{142}$ After the decision was handed down Republika Srpska's Prime Minister Dodik officially apologized to Bosnia highlighting, however, that all parties were involved in atrocities committed during the war. ${ }^{143}$ The Serbian government has not taken such a step.

\section{A Res Judicata}

It is regrettable that jurisdiction occupied such a large amount of the Court's time and resulted in such extensive and contradictory judicial consideration. The fact that jurisdiction lay in the Court finding the 1996 judgment had res judicata force and that this finding carried with it 'necessary implications' is problematic. Eight judges ${ }^{144}$ expressed serious concern with rather simplistic classification of the 1996 judgment as res judicata and that being the end of the matter. Their main concern was the lack of explanation behind the reasoning as to the application of res judicata, especially in the face of seeming inconsistency with the NATO cases. In the NATO cases, Serbia and Montenegro's UN membership was deemed not to have existed at the relevant time, and thus it was not granted effective access to the Court. The Court's finding on jurisdiction in the Genocide case is thus at odds with the NATO cases, although in them there was no res judicata issue. ${ }^{145}$

Whilst the NATO cases did not have binding force of res judicata, as they were not between the same parties, the fact that inconsistencies were not drawn out and discussed by the majority has left room for confusion and contradiction as predicted in the dissenting opinion of Vice-President Al-Khasawneh. ${ }^{146}$ Yet, it is also acknowledged that the Court's application of res judicata to the 1996 judgment successfully allowed the Court to avoid a difficult situation. Had the Court examined jurisdiction de novo, it would have been faced with either setting aside its own previous ruling and throwing out the case on a preliminary objection after 14 years of litigation, or finding against the NATO cases. Thus reliance on res judicata, though a very formalistic approach, enabled it to avoid

142 Bruno Vekaric in Vesna Peric Zimonjic, 'Rights: Belgrade Held Not Guilty of Genocide in Bosnia,' Global Information Network (New York), 26 February 2007, 1.

143 SwissPeace, Bosnia and Herzegovina: conflict and cooperation (2007) <http://www.swisspeace.ch/typo3/fileadmin/user_upload/pdf/FAST/Updates/2007/Bosnia_Update_107.pdf at 26 March 2008.

144 Vice-President Al-Khasawneh; Judges Owada, Tomka, Ranjeva, Shi, Koroma Skotnikov; Judge ad hoc Kreca.

145 NATO cases, [2004] ICJ Rep 279; [2004] ICJ Rep 429; [2004] ICJ Rep 575; [2004] ICJ Rep 720; [2004] ICJ Rep 865; [2004] ICJ Rep 1011; [2004] ICJ Rep 1160; [2004] ICJ Rep 1307; [1999] ICJ Rep 761; [1999] ICJ Rep 916.

146 Dissenting Opinion of Vice-President Al-Khasawneh, International Court of Justice, 26 February 2007 $<$ http: $/ /$ www.icj-cij.org/docket/index. php?pl=3\&k=f4\&case $=91 \&$ code=bhy\&p3 $=4>$ at 26 March 2008, [28]. 
this dilemma. ${ }^{147}$ Furthermore, the finding of jurisdiction under Article IX, has clarified the previously ambiguous scope of the Articleicle and its effect on states.

The Court's dealing with issues of jurisdiction undoubtedly contributed to the lengthy 14 year proceedings. Jurisdiction was raised in the 1996 and 2003 judgments, and again entertained in 2007. Further, since the final basis of jurisdiction was established through the application of res judicata to the 1996 findings, such a lengthy, cautious approach can been seen as 'an excess of procedural caution' resulting in extended proceedings and impacting upon the Court's ability to render expeditious justice. ${ }^{148}$ However, the importance of the Court's clarification that it had effective jurisdiction cannot be undervalued.

\section{B Dolus specialis}

The case clearly illustrates difficult evidentiary issues in establishing the dolus specialis of genocide. Bosnia strongly argued that intent should be inferred from the widespread killings that occurred on Bosnian territory. The Court adopted a strict approach to establishing the dolus specialis and would not infer genocidal intent from widespread killings, finding that only one instance of genocide had occurred, that of July 1995 at Srebrenica. The Court had difficulty on the question of inferring the dolus specialis from conduct and struggled to reconcile contemporary practice in international criminal law with an interstate claim. This, coupled with the Court's refusal to consider certain evidence, made the task of establishing the dolus specialis all the more difficult.

Professor Antonio Cassese has attacked the judgment as demanding 'an unrealistically high standard of proof. ${ }^{149}$ For others it 'was unfortunate' the Court declined to find genocide occurred in other instances of mass killings and rapes across Bosnia. ${ }^{150}$ According to Professor Dworkin, however, genocide is something serious and cannot be applied in all circumstances, thereby supporting the Court's finding that Serb intentions regarding the Bosnians were far from clear '[i]f the campaign was at its core an attempt to remove the Bosnian Muslims from a particular patch of territory, rather than eradicate all or many of them, it was not genocide in the terms of the 1948 convention'. ${ }^{\prime 51}$ Given this absence of clarity, to equate Serbia's conduct with the Armenian and Jewish

147 Thomas M Franck, David Golove, Benedict Kigsbury and Santiago Villalpando, 'Implications of the World Court's Decision in the Genocide Case (Bosnia-Herzegovina v Serbia)' (Report of panel discussion at the Institute for International Law and Justice, New York University School of Law, 12 April 2007) <http://iilj.org/newsandevents/documents/Genocidereport_000.pds at 26 March 2008.

148 Terry D Gill, 'The "Genocide" Case: Reflections on the ICJ's decision in Bosnia and Herzegovina v Serbia' (2007) 2 Hague Justice Journal 43, 44.

149 Caroline Tosh, Genocide Acquittal Provokes Legal Debate (2007) Institute for War and Peace Reporting <http://iwpr.net/p=tri\&s=f\&o=333772\&apc_state=henh> at 26 March 2008.

150 Michael J Matheson, The American Society of International Law Council Newsletter Comment: The International Court of Justice's Decision in Bosnia and Herzegovina v Serbia and Montenegro (2007) American Society of International Law <http://www.asil.org/newsletter/councilcomment/> at 26 March 2008.

151 Anthony Dworkin, The Law and Genocide: Bosnia, Serbia and Justice (2007) Human Rights Agenda Association <http://www.rightsagenda.org/main.php?id=82\&lg=en> at 26 March 2008. 
genocides seems inappropriate. Furthermore, a pronouncement by the Court of Serbia's responsibility for genocide would have further polarised an already volatile region. ${ }^{152}$ Despite this argument, President Higgins, has denied that the judgment was a political compromise. ${ }^{153}$ Nevertheless, Posner argues that it still remains an open question whether the proceedings 'may end up illustrating the limits of international law, rather than vindicating its ideals'. 154

\section{State Responsibility}

There appeared to be some confusion regarding the nature of the responsibility of the state under the Genocide Convention. The Court established that through use of Article IX, it has the power to determine questions of state responsibility in relation to both acts of genocide and failure to prevent. Such clarification is of obvious value to the development of international law and paves the way for future cases claiming state responsibility for this morally repugnant crime. Five judges emphasised that states cannot commit genocide and concern was raised by Judges Tomka and Skotnikov, going a step further to stress that the Court was not the appropriate forum for the determination of individual criminal responsibility.

Certain documents that may have provided the causal link between the Serbian government and the VRS were not allowed as evidence by the Court as the ICTY permitted them to remain classified due to Serbia's national security concerns, a classification which the ICJ would not be able to respect if it were to examine the documents. Vice-President Al-Khasawneh believed the Court provided inadequate reasons for not examining the documents, such as state sovereignty, a fear of taking sides or embarrassment if Serbia refused the Court's order. ${ }^{196}$ This sets a standard whereby 'other states with genocidal ambitions may similarly be successful in withholding evidence ... that would be dispositive of specific intent. 157

152 Scott Shackelford, 'Holding States Accountable for the Ultimate Human Right Abuse: A Review of the International Court of Justice's Bosnian Genocide Case' (2007) 14 Human Rights Brief 21, 23.

153 Marlise Simons, 'World Court Absolves Serbia of Genocide Charge', International Herald TribuneEurope (The Hague), 26 February $2007<\mathrm{http}: / / \mathrm{www}$. iht.com/articles/2007/02/26/news/hague.php> at 2 February 2008. See also David Luban, Timid Justice- The ICJ Should Have Been Harder on Serbia (2007) Global Policy Forum <http://www.globalpolicy.org/intljustice/icj/2007/0228timid.htm> at 6 April 2008.

154 Eric A Posner, 'Sins of the Fatherland', The Boston Globe (Boston), 5 March 2006, E4.

155 The issue of a state being responsible for criminal acts is controversial. Even though only provisionally adopted by the ILC's Articles on State Responsibility, above $\mathrm{n} 79$, draft art 19 drew a distinction between international delicts and international crimes. Draft art 19 was ultimately replaced by what would become arts 40 and 41. See Pierre Bodeau, James Crawford and Jacqueline Peel, The ILC's Draft Articles on State Responsibility - Towards Completion of a Second Reading (undated) Lauterpacht Centre for International Law, University of Cambridge <http://www.Icil.cam.ac.uk/Media/ILCSR/ajil2000(sf).doc> at $26 \mathrm{March}$ 2008.

156 Merdijana Sadovic, Could Key Records have Altered ICJ Ruling? (2007) Institute for War and Peace

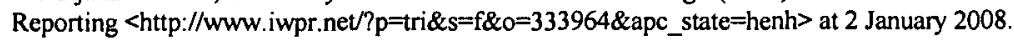

157 Shackelford, above n 152. Scott Shackelford, 'Holding States Accountable for the Ultimate Human Right Abuse: A Review of the International Court of Justice's Bosnian Genocide Case' (2007) <http://www.wcl.american.edu/hrbrief/14/3shackelford.pdf? rd=1> at 26 March 2008. 
Even though the Court applied the test of effective control, it did not give sufficient reasons as to why it could not apply the overall control test. Despite evidence of close association, the Srebrenica genocide could not be attributed to Serbia nor was Serbia directly complicit in acts of genocide. For Bosnians much grief stemmed from the Court stopping short of finding Serbia responsible for the Srebrenica genocide. ${ }^{158}$ The ICJ 'has retarded decades of lawmaking in the area of accountability for mass atrocities' as it should not have drawn a legal and a de facto distinction between the VRS and the FRY, as there was a relationship between the official leadership of the FRY and the armed forces of Republika Srpska. ${ }^{159}$ This is again indicative of the Court struggling with principles of international criminal jurisprudence in an interstate claim.

\section{Failure to Prevent and Cooperate}

The case is important as it found there was a positive duty to prevent the occurrence of genocide, and that Serbia violated this duty. The Court, however, failed to outline the scope of the prevention duty. The judgment missed an opportunity to

give the international community some guidance on the content of the positive obligations to prevent the occurrence of what constitutes the gravest of crimes against humanity, and on the appropriate measures for redress and rehabilitation of its victims.

Even more problematic is the position of a state willing and able to take measures but without any jurisdiction over territory or control over persons, as highlighted by Judge Tomka. ${ }^{161}$

The case is significant in finding that Serbia failed in its duty to fully cooperate with the ICTY in surrendering outstanding war criminals, who are suspected to be harboured in Serbia, for prosecution, thereby violating its obligation to cooperate fully with the Tribunal under Article VI of the Genocide Convention. For Professor Cassese, holding Serbia in violation of the Genocide Convention 'can pose all sorts of problems for Belgrade, unless it acts quickly and makes arrests' of key war criminals. ${ }^{162}$ This can be positively viewed as fostering further cooperation between Serbia and the ICTY concerning the surrender of Radovan Karadžić and Ratko Mladić. The Presidency of the European Union ('EU'), upon the delivery of the judgment, called upon Serbia to now take steps to 'distance itself from the crimes committed by the Milosevic

158 Wood, above $\mathrm{n} 141$

159 Makau Mutua, The American Society of International Law Council Newsletter Comment: The International Court of Justice's Decision in Bosnia and Herzegovina v Serbia and Montenegro (2007) American Society of International Law <http://www.asil.org/newsletter/councilcomment $>$ at 26 March 2008.

160 Andrea Gattini, 'Breach of the Obligation to Prevent and Reparation Thereof in the ICJ's Judgment' (2007) 18 European Journal of International Law 695.

161 Separate Opinion of Judge Tomka, International Court of Justice, 26 February 2007 <http://www.icj-cij.org/docket/index.php?pl=3\&k=f4\&case=91 \&code=bhy\&p3=4> at 26 March 2008, [66]-[67].

162 Marlise Simons, 'Mixed Ruling on Genocide Still Puts Pressure on Serbia', New York Times (New York), 6 March 2007, 10. 
regime'. ${ }^{163}$ The Presidency called for Serbia to make all efforts to cooperate with future endeavours of international criminal justice by not ceasing to protect war criminals suspected of hiding in Serbia. ${ }^{16}$

The ruling has an impact reaching beyond Serbia, as it can be inferred that any country sheltering Karadžić and Mladić would now be considered to be in violation of the Convention. Furthermore, the ruling will affect other fugitives, in particular those accused in the Rwanda genocide. According to Professor David Scheffer, the ruling confirmed that "'all states have an obligation" to take action against people accused of genocide "and part of that is apprehending them", ${ }^{165}$ which can only be achieved through state cooperation.

\section{E Reparations}

Satisfaction through declaration of the Court was the only reparation deemed appropriate. Despite finding Serbia in breach of obligations to prevent and punish the Srebrenica genocide, the Court could not find a direct causal nexus between Serbia's actions (or inaction) and loss suffered. The Court's approach has been criticised, with suggestions that the burden of proof should have shifted to Serbia, requiring it establish that despite it taking appropriate measures, the tragic events at Srebrenica would have still unfolded. ${ }^{166}$ Furthermore, concern has been expressed in relation to the Court's use of Corfu Channel Case ${ }^{167}$ in holding satisfaction as appropriate reparation. Given that the nature and consequences of the two cases differ so greatly, the 'satisfaction is appropriate' principle should not be so readily applied. ${ }^{168}$

Bosnia's overall disappointment was reinforced through the Court's refusal to deal with reparations, which is viewed as a trivialisation of their suffering and the lives lost. Fatija Suljic, who lost her husband and three sons in Srebrenica has responded '[t]his makes me cry. This is no verdict, no solution. This is disaster for our people'. ${ }^{169}$ The fact that the Court did not find upon the more substantial merits was of obvious disappointment for Bosnia, which was left without concrete remedy. Serbia, on the other hand, was relieved that it did not have to pay damages. Had the Court found Serbia responsible for genocidal acts or complicity, the Court would have been more likely to hold Serbia responsible for financial reparations, which would have seriously impacted on Serbia's fledging

163 Common Foreign and Security Policy Statement, 'EU Presidency Statement on the International Court of Justice's Judgment' (Statement, 26 February 2007)

<http://www.eu2007.de/en/News/CFSP_Statements/February/0226Serbien.html> at 26 March 2007.

164 It has long been maintained that war criminals sought refuge in Serbia, General Mladic in particular. The Court held that Serbia's subsequent failure to transfer Mladic to the ICTY amounts to ongoing violation of its obligations under art VI of the Genocide Convention: Genocide case, International Court of Justice, 26 February $2007<h t t p: / w w w . i c j-c i j . o r g /$ docketindex.php?pl=3\&k=f4\&case=91\&code=bhy\&p3=4> at 26 March 2008, [450].

165 Simons, above $\mathrm{n} 162$

166 Christian Tomuschat, 'Reparation in Cases of Genocide' (2007) 5 Journal of International Criminal Justice 905,908

167 [1949] ICJ Rep 35.

168 Tomuschat, above n 166, 910.

169 David Byers, 'Court clears Serbia of Srebrenica genocide', The Times Online, 26 February 2007 <http:/www.timesonline.co.uk/tol/news/world/europe/article1441632.ece> at $26 \mathrm{March} 2008$. 
economy. ${ }^{170}$ Further, the declaratory findings already act as a moral stigma upon a state that maintains that the loss during the war was not solely perpetrated by one side.

The Court's finding on reparation can also be more positively viewed. Had financial compensation been awarded it is possible a challenge to that compensation would have followed, thereby preventing the region from reaching closure. ${ }^{171}$ Another argument in support of the Court's approach is that the ICJ is not an appropriate forum to accurately calculate adequate compensation for the loss of 7000 lives and property. Such logic would not, however, pertain to awarding symbolic compensation.

Finally, it can be argued that the already strained Balkan regional relations would have been under further pressure, had Serbia been ordered to pay damages. Rather, there are now hopes for reconciliation. EU High Representative for the Common Foreign and Security Policy, Javier Solana, expressed praise for this aspect of the judgment, and applauded the fact that 'there is no collective punishment' and that 'the highest tribunal in the world has closed that page'. ${ }^{172}$ The EU Presidency, currently dealing with further incorporating the region into the EU, also focused on the importance of regarding the verdict as a step towards reconciliation and urged all sides to respect the judgment. ${ }^{173}$

\section{CONCLUSION}

This was a long and difficult case for the Court, which struggled with complex jurisdictional issues and the appropriateness of finding a State responsible for genocide. Notwithstanding this, the fact that a state can clearly be held responsible under international law for violations of the Genocide Convention makes the case most important.

Aside from the Court protracting the jurisdiction question for so many years and, to some degree, blurring the distinction between public international law and international criminal law in resolving an interstate dispute, the case has left several important issues unresolved. The Court did not clarify the status of the FRY's UN membership nor did it reconcile inconsistencies with the NATO cases. The Court also did not clarify the appropriateness of using rules of international criminal law in determining whether there can be inference of genocidal intent from acts. Nor did the Court clarify when financial reparations are appropriate. Indeed, the majority's underplaying of reparations and holding that the declaratory finding amounted to 'appropriate satisfaction' seems an ironic and disappointing conclusion.

The case has placed the parties further apart than ever. Even though the judgment eased Serbia's domestic and international position, the Bosnians view

170 Marlise Simons, 'Court Still Weighing Genocide Case from Milosevic Era', New York Times (New York), 18 June 2006, 6 .

171 Gill, above $\mathrm{n} 148,47$.

172 Javier Solana, ICTY Weekly Press Briefing (2007) <http://www.un.org/icty/briefing/2007/pb070314.htm> at 14 March 2007.

173 Common Foreign and Security Policy Statements, above $n 163$. 
it as a defeat. The overall effect of the judgment appears disappointing as the case will neither reconcile the parties nor will it bring them closer together. It is nonetheless hoped it is a positive step playing some role in healing the residual wounds of war. 